\title{
Hebdomadal Patterns of Compensatory Behaviour: Weekday and Weekend Housework Participation in Canada, 1986-2010
}

Kamila Kolpashnikova ${ }^{1}$, University of Oxford

Man-Yee Kan, University of Oxford

[This is authors' final version of an article accepted by the Work, Employment and Society journal on July 15, 2019.]

\begin{abstract}
Quantitative housework research focussed on aggregate weekly hours, which are inadequate in revealing hebdomadal compensatory behaviour in housework participation because such behaviour is likely to occur on weekends when couples have more time to do housework. This article extends the existing theoretical frameworks by accounting for the hebdomadal patterns in routine and non-routine housework tasks. Employing five time-use waves of the Canadian General Social Survey, our study shows that the hebdomadal compensatory behaviour applies both to women and men. Equal-earner and breadwinner wives compensate for their low levels of weekday housework participation by doing more routine housework on weekends. Similarly, husbands also increase their time on routine housework on weekends. Therefore, compensatory behaviour is more likely to depend on hebdomadal time availability rather than on the neutralisation of gender deviance in the labour market (gender deviance neutralisation). Some evidence of the gender deviance neutralisation, however, cannot be completely ruled out.
\end{abstract}

\footnotetext{
${ }^{1}$ Corresponding author: Kamila Kolpashnikova, Department of Sociology, University of Oxford, 42-43 Park End Street OX1 1JD, Oxford, United Kingdom. Phone: +44 (0)1865 281338. Email: kamila.kolpashnikova@ sociology.ox.ac.uk.
} 
Keywords: compensatory behaviour on weekends, gender deviance neutralisation, hebdomadal time availability, housework, time use on weekends 


\section{Hebdomadal Patterns of Compensatory Behaviour: Weekday and Weekend Housework Participation in Canada, 1986-2010}

Kamila Kolpashnikova², University of Oxford

Man-Yee Kan, University of Oxford

Earlier housework research established that breadwinner women compensated for breaking the gender norms in the labour market by reinforcing traditional gender roles at home (by neutralising gender deviance). Therefore, breadwinner women compensated by doing more housework than their contribution to household resources would warrant or require under the resource-based predictions (Brines, 1994; Greenstein, 2000). In housework literature, this pattern of behaviour is often referred to as a compensatory or gender-neutralising behaviour (Evertsson and Nermo, 2004), which is a notion derived from the deviance and self-discrepancy theories in social psychology (Higgins, 1987; Sykes and Matza, 1957).

However, in the last three decades, women's position at work and home has improved substantially. In fact, the improvements were so palpable that some studies expressed doubt that gender and the relations of power still applied to housework participation in post-industrial countries and that instead, the differentials in economic resources could account for most differences in the domestic division of labour (Gupta, 2007; Killewald and Gough, 2010; Sullivan, 2011). Thus, Killewald and Gough (2010) bring new evidence that the compensatory behaviour of breadwinner women reported in earlier studies was due to a modelling error and

\footnotetext{
${ }^{2}$ Corresponding author: Kamila Kolpashnikova, Department of Sociology, University of Oxford, 42-43 Park End Street OX1 1JD, Oxford, United Kingdom. Phone: +44 (0)1865 281338. Email: kamila.kolpashnikova@ sociology.ox.ac.uk.
} 
because of the non-linear effects of personal income. They argue that no such compensatory and gender-neutralising behaviour is evident in more recent data (Gupta, 2007; Killewald and Gough, 2010; Sullivan, 2011).

Compensatory behaviour in housework, however, can be driven by other processes than the need to neutralize the breaking of the dominant gender norms (gender deviance). The present article argues that recent housework studies did not test the compensatory behaviour in housework adequately because they analysed the data aggregated at the week level, ignoring the possibility of the compensatory behaviour variation by weekday, depending on time availability. We contend that the aggregated hebdomadal data do not account for the variation in the time constraint, which both women and men experience depending on the day of the week. The hebdomadal differences arise because paid work time, as well as other commitments, varies throughout the week and hinders other individual activities, including housework and unpaid work, in general.

Although scholars reported the gap between weekday and weekend housework participation before (Hook, 2017; Craig, 2007; Gupta and Sayer, 2014; Ruppanner and Treas, 2015), the major theoretical frameworks regarding the compensatory behaviour were not adjusted to account for the hebdomadal variation. The present article argues that the patterns of housework participation must be analysed separately by the day of the week precisely because the compensatory behaviour in housework fluctuates depending on whether it was done on a weekday or a weekend. We use the conventional tests of gender deviance neutralisation in quantitative housework research, that is, the tests of whether the patterns of housework participation diverge from those predicted by the resource contribution, also utilized in Brines (1994), Greenstein (2000), Killewald and Gough (2010), and Hook (2017). This study 
contributes by remedying the oversight of hebdomadal variation in the previous literature and discusses the theoretical implications of such variation, using the time use diary data of the Canadian General Social Survey as an example. To foreshadow our results, this study confirms that the aggregation of weekday and weekend data conceals the compensatory behaviour on weekends, especially among women in routine housework tasks.

\section{Theoretical Framework}

\subsection{Gender-centred and Resource-based Frameworks}

Housework research relies on a few main theoretical frameworks, which can be broadly categorised as gender-centred and resource-based. On the one hand, the gender-centred perspective on the gendered division of housework emerged from the theories on gender roles in 1980s and 1990s (Blair and Lichter, 1991; Presser, 1994) and later on the gender display (Baxter and Hewitt, 2013; Bianchi et al., 2000; Gupta, 2007) and the 'doing gender' approaches (Artis and Pavalko, 2003; Deutsch, 2007; Evertsson and Nermo, 2004; Kan, 2008a; Kolpashnikova, 2016; Kolpashnikova, 2018; West and Zimmerman, 1987). Many of these studies were also present in the qualitative research of housework (McLaughlin and Muldoon, 2014; Mthombeni and Casey, 2019). For example, in the in-depth interviews of fathers residing in Northern Ireland, McLaughlin and Muldoon (2014) explore the work-life tensions that the new ideals of fatherhood brought on men, who tried to balance both workplace and societal expectations around the role of a father. Similarly, in the semi-structured interviews of lesbian couples in the northeast of England, Mthombeni and Casey (2019) find that 'doing' one's gender is apparent not only in heterosexual but also in same-sex couples. 
On the other hand, the resource-based framework includes three main arguments: relative resources, time availability, and absolute resources. According to the relative resources approach, the more resources one has relative to one's spouse, the more bargaining power one accumulates to forgo housework responsibilities, thus exchanging one's resources for spouse's housework (Blood and Wolfe, 1960; McElroy and Horney, 1981). The bargaining process is also important in the time availability argument. It posits that time is the resource that becomes important in the couple's bargaining with each other. One who has more time does more housework (Blood and Wolfe, 1960; Hook, 2004). Bargaining as the main process behind the division of housework is questioned by the third argument, the absolute resources approach. Gupta (2007) and Killewald and Gough (2010) argue that absolute resources (commonly measured by waged income), not relative, matter more in the explanation of housework participation. Their argument is often referred to in housework literature as the autonomy perspective because waged income also measures the level of individual economic autonomy. The economic autonomy in housework research highlights the ability to outsource housework and hire help. This approach posits that individuals may have enough absolute resources to make autonomous decisions about their own unpaid work, rather than always having to negotiate and bargain with their partners as the previous two arguments state. The resource-based frameworks do not negate the effect of gender on the division of housework, however, they assert that the effects of gender are indirect, working through its effect on economic resources (Bittman et al., 2003).

In earlier quantitative housework research, Brines (1994) demonstrated that the gendercentred approach could predict the housework participation of economically dependent men better than the resource-based model. Thus, Brines' (1994) study shows that consistent with traditionally 'masculine' performances, dependent men eschew housework, even though they do 
not contribute economically as much as their higher-earning partners. Greenstein (2000) adds that the gendered performances of economically independent wives are also congruous with a more traditional construct of 'femininity', where they do more core housework, even though they earn more than their partners do. As a result, the gender-centred approach of the quantitative housework research burgeoned concurrently to the need to explain these contradictory patterns, which went against the predictions of the resource-based perspectives (Kolpashnikova, 2018; Brines, 1994; Greenstein, 2000). The patterns of behaviour among breadwinner wives revealed in the studies of Brines (1994) and Greenstein (2000) epitomise the compensatory genderneutralising behaviour later challenged by Killewald and Gough (2010).

Analogous results were reported in other liberal regime states. For instance, Lyonette and Crompton (2015) report similar results for British and Bittman et al. (2003) - for Australian women's participation in housework, whereas Evertsson and Nermo (2004) report the genderneutralising behaviour for American but not for Swedish women. The compensatory and genderneutralising behaviour of economically independent women, therefore, might be more evident in liberal regime countries than in socio-democratic countries, where perhaps gender-egalitarian expectations are already prevalent in housework and therefore no compensatory behaviour is extant (Esping-Andersen, 1990; Kitterød and Pettersen, 2006).

On the other hand, Greenstein (2000) and Brines (1994) show that gender neutralising behaviour is not the prerogative of only breadwinner wives. They present evidence that dependent men were also actively eschewing housework, even though they did not contribute as much economically. Breadwinner wives neutralise their non-traditional gender behaviour in the labour market (where they 'undo gender') by doing more housework and dependent men-by doing less housework at home (where they 'do' or 'display' gender) (Lyonette and Crompton, 
2015). Under the propositions of the gender-centred framework, breadwinner wives and dependent men 'do' traditional gender in housework because they are pressured by the weight of internalised normative attitudes, expectations and social sanctions.

Although earlier research reported more evidence for the gender display and affirmed gender-deviance neutralising and compensatory behaviour (Brines, 1994; Greenstein, 2000), in more recent research, Killewald and Gough (2010) find that the compensatory gender display for wives with higher levels of income is not evident from more recent data. Similarly, Sullivan (2011) criticises the gender-neutralisation assumption on the grounds that women who earn more than their partners are no longer rare to warrant gender-deviance neutralisation. Thus, the recent quantitative housework research attributes the compensatory behaviour found in earlier studies largely to modelling errors and outdated data.

Furthermore, Kolpashnikova (2018) shows that breadwinner men's participation in housework, particularly cooking, exceeds that what would have been expected relative to their economic contribution. Such a pattern among breadwinner men could not be accounted for by either the resource-based framework or the gender-centred approach. The explanation of all the above patterns, however, can be provided when the hebdomadal differences of housework participation are taken into account, as discussed below.

\subsection{Urge for a New Theoretical Framework Accounting for Hebdomadal Patterns}

Since the Babylonians, humanity has conditioned itself to expect a working cycle of 7 days. A week, as any unit of time, by itself is nothing but a socio-cultural construct around which people have organised their lives to the point that the arrangement feigned the natural order of things (Adam, 1990; Sorokin and Merton, 1937; Banister, 2011). This hebdomadal social 
construction had profound consequences on our behaviour, perhaps even exceeding the influence of monetary resources and even of our genders. Poor and rich, cisgender and genderqueer, most of us are constrained by a 7-day cycle.

The hebdomadal constraint applies to all activities, including housework. The working week in most post-industrial societies is ordinarily from Monday to Friday, that is, most work-related activities take place during regular weekdays ${ }^{3}$. On the other hand, most leisurely and householdmaintenance activities are postponed to weekends. Time use researchers show how participation in paid and unpaid work, as well as leisure in Europe, varies depending on the day of the week by plotting the temporal graphs (tempograms) of daily activities (see Glorieux, Mestdag, and Minnen, 2008; Fiorini and Keane, 2014). They confirm visually that there are profound differences in how the hebdomadal constraint structures our daily lives. Craig (2007) also shows that employed women tend to shift their housework burden to weekends, suggesting the presence of compensatory behaviour with a hebdomadal pattern.

The recent housework studies within the resource-based and gender-centred frameworks do not consider the differences in housework participation by weekday and weekend. The oversight of the weekly patterns in housework participation was remedied in Hook (2017), who showed that the patterns observed in the allocation of time to housework differ by whether the task is performed on a weekday or weekend. Hook (2017) demonstrates that the resource-based explanations do not account well for housework participation on weekends.

Overall, according to the previous research, the resource factors and gendered expectations influence housework participation differently during a regular week, specifically when the patterns on weekdays are compared to those on weekends. The differences in how theoretical

\footnotetext{
${ }^{3}$ In some societies, notably in the Middle East, the working week starts on Sunday and ends on Thursday.
} 
frameworks apply depending on the day of the week can also be expected (Hook, 2017). Since there is, on average, more time pressure due to work responsibilities on weekdays than on weekends, it can be expected that:

H1.1.: Because resource bargaining and outsourcing are more likely to occur on weekdays than on weekends due to the time constraint on weekdays, the association between resources and housework participation will be stronger on weekdays than on weekends.

Furthermore, we can extend the extant theoretical arguments by noting that the patterns of participation in housework may differ by housework task (Killewald and Gough, 2010). There might be hebdomadal compensatory behaviour patterns observed in some housework tasks while not in others. The aggregate measures of housework and the use of the week totals may obscure these nuances.

Thus, the regularity and time-demanding nature of housework tasks can affect the hebdomadal time constraint as well as the degree of task participation. When tasks are timedemanding, there are more occasions and need to reschedule for the weekend (Kan, 2008a; Kan and He, 2018; Kan, Sullivan, and Gershuny, 2011). Tasks such as cooking and cleaning ordinarily require more time and have to be done more regularly. On the other hand, maintenance and repairs can take up a lot of time but do not have to be daily. Conversely, although shopping is often done routinely, it also does not often take as much time as the other tasks. Therefore, because cooking and cleaning, as well as maintenance, are more timedemanding, they might be more likely to be postponed to weekends than shopping when there are higher demands from other activities such as work on weekdays. 
Taking the demanding nature of some housework tasks over others, Hypothesis 1.1 can be modified to the following:

H1.2.: The association between resources and housework participation will be stronger on weekdays than on weekends, particularly in routine housework tasks.

\subsection{The New Theoretical Framework: Compensatory Behaviour Based on Gender Deviance Neutralisation and Compensatory Behaviour Based on Time Availability}

There is a gap in the literature regarding the analysis and testing of compensatory behaviour. For the evidence of the compensatory behaviour, the weekend behaviours of breadwinner women should be analysed and compared to their own housework participation on weekdays, whereas most previous research focussed on comparing dependent and equal-earner wives with breadwinner wives.

Moreover, although previous research lays out the ground for the expectation of differences between weekday and weekend housework (Hook, 2017; Craig, 2007; Gupta and Sayer, 2014; Ruppanner and Treas, 2015), the idea did not result into the revision of the two main theoretical frameworks. Gupta and Sayer (2014) express their concerns about the inadequacy of the resource-based framework, given the pattern disparity on weekdays and weekends. This theoretical revision of the leading frameworks is long overdue, especially in the light of new contradictory empirical findings (Kolpashnikova, 2018). The contradictory pattern revealed in Kolpashnikova (2018) is not discussed in Killewald and Gough (2010) and Hook (2017) because they restrict their analyses to wives but do not include husbands. 
The premise of the compensatory behaviour based on gender deviance neutralisation, established and challenged in the previous literature (Brines, 1994; Greenstein, 2000; Killewald and Gough, 2010; Hook, 2017), posits that when a spouse involves in gender-deviant behaviour in the economic sphere such as 'committed' by a breadwinner wife or a supported husband, social expectations push those individuals into reasserting, or 'doing', their traditional gender in other spheres (West and Zimmerman, 1987; Evertsson and Nermo, 2004). Within the housework research, the gender deviance neutralisation hypothesis expects economically independent wives to compensate by doing more housework, whereas economically dependent husbands would reassert their traditional gender by eschewing housework at home altogether (Brines, 1994).

Combined with the idea of hebdomadal variation, the compensatory behaviour based on gender deviance neutralisation would mean that breadwinner wives do more housework on weekends, whereas dependent men do almost no housework both on weekdays and on weekends (compensatory behaviour proposition 1). Yet, the recent literature tests this hypothesis by comparing breadwinner wives to equal earner and economically dependent women or dependent men to equal earner and breadwinner men, whereas the main theoretical idea in deviance neutralisation is the compensation by the same-status individuals. The following can, therefore, be expected if the hebdomadal gender deviance neutralisation proposition is confirmed:

H2: Compensatory behaviour on weekends can be observed stronger among breadwinner wives and not among dependent husbands (the hebdomadal gender deviance neutralisation hypothesis). 
The gender deviance neutralisation thesis implies that compensatory behaviour is driven predominantly by gendered mechanisms. That is to say, within this framework, compensatory behaviour is explained solely by the need for 'doing' and achieving gender. However, an alternative explanation is possible. Putting off housework (or other activities) until weekend has also to do with time availability. Wives and husbands postpone their housework participation on weekdays and do more on weekends. Therefore, compensatory behaviour might also be driven by factors other than gender deviance neutralisation. In such a case, the pattern of commensurate compensatory behaviour would be evident among men as well as women. If compensatory behaviour occurs both among husbands and wives, then the time availability factors play a more salient role in the explanation of weekday/weekend housework participation disparities. The hebdomadal pattern of time availability could also be able to account for the non-traditional gender behaviour among men reported by Kolpashnikova (2018).

Thus, compensatory behaviour does not always have to be gendered. First, compensatory behaviour may be caused by insufficient time. If there is a compensatory behaviour on weekends both among women and men, then the hebdomadal time availability thesis can be confirmed that both women and men tend to participate in compensatory behaviour on weekends (compensatory behaviour proposition 2). However, the previous studies have not tested the proposition among men, except asserting breadwinner men's non-traditional patterns of housework participation (Kolpashnikova, 2018). Yet there is no explicit or sufficient theoretical explanation in Kolpashnikova (2018) regarding the unusual patterns of behaviour among men but the message is clear-there is a gap in theory, which needs to be addressed (Gupta and Sayer, 2014).

Both men and women are limited in time by employment and other daily activities on weekdays but not so much on weekends. Hence, according to our hebdomadal time availability 
proposition, men are as likely to do more housework on weekends as women are. This could potentially explain both the results for women in Killewald and Gough (2010), as well as for men in Kolpashnikova (2018). Therefore, the present study also expects to find patterns of such compensatory, but not gender deviance neutralisation, behaviour based on hebdomadal time availability among men as well as women:

H3: Compensatory behaviour on weekends can be observed among both wives and husbands (the hebdomadal time availability hypothesis).

\section{Methodology}

\subsection{Data}

This study compared the time spent on household tasks using five cycles of the Canadian General Social Survey (GSS) (Statistics Canada, 2011) between 1986 and 2010. The GSS collected daily time diary data, which are less likely to reflect the social desirability bias (Hofferth and Casper, 2007) than traditional stylised surveys (Kan, 2008b; Kan and Pudney, 2008). This study, therefore, provided more accurate estimates to those proposed by the previous research (Brines, 1994; Greenstein, 2000; Gupta, 2007; Killewald and Gough, 2010), based on the self-reported measures of housework.

The main sample is restricted to married and cohabiting individuals. We focus on married individuals but we also recognise that the sample of married and cohabiting women and men must be different from non-married women and men in their housework participation as well as 
other factors (Kolpashnikova, Kan, and Shirakawa, 2019a; Kolpashnikova, Kan, and Shirakawa, 2019b; Hertog and Iwasawa, 2011; Zhou, Wu, and He, 2017). However, this article focusses mostly on the division of labour among married women and men because resource-based mechanisms, especially those based on bargaining mechanisms, are less likely to apply to nonmarried women and men. Students and retirees were dropped from the analytic sample because bargaining and gender display processes could be observed and were more pertinent to couples where both partners could potentially work. The final total sample included 9,896 men's persondays and 11,161 female person-days spanning the period of 1986-2010. To control for data variation depending on the survey year and on the province of respondents' residence, the dummy variables for years and provinces were also included in the models.

\subsection{Dependent Variables}

The dependent variables were measured as the time spent on three groups of domestic tasks: routine housework tasks (cooking and cleaning), shopping and services tasks and home maintenance and repairs. Table 1 summarises the descriptive statistics for the main domestic tasks. There is a significant difference between weekday and weekend time spent by women and men for all tasks. For instance, Table 1 shows that on an average weekday, women spent almost 40 minutes less on all domestic housework than on a weekend day, whereas the weekdayweekend gap among men in housework was higher than among women—68 minutes.

Housework time was modelled at two stages. First, because there might be a selection bias and the sample of those who do housework might differ from those who do not report doing housework, the Heckman adjustment method was employed (Heckman, 1979). In the second stage, the models include only those who report doing housework with the adjustment for the selection bias. Unlike traditional surveys, time diaries focus only on one day and not on a more 
extended period, which could allow a wider spread of non-zero values for housework measures. The deleted zeros include both 'real' zeros of people who never participate in the activity as well as those who happened not to participate in the activity on the diary day. The selection bias as a result of these factors is addressed by using the Heckman adjustment to coefficients.

[Table 1 here]

\subsection{Independent Variables}

The measure of relative resources was used to test the resource-based framework. The income transfer variable was defined as (personal income - partner's income)/ (personal income + partner's income). The measure ranges between -1 and 1 , where higher values mean a higher level of economic dependency and 0 is neutral. The use of alternative measures (absolute resources and time availability) result in similar outcomes summarised in the present study. For details of using other measures for the resource-based framework see Hook (2017).

Two other measures of resources, specifically of the absolute resources, or the autonomy, were personal income and homeownership and were included in the selection models. There were three dummy variables indicating employment status: full-time workers, part-time workers and individuals with other employment statuses (unemployed, individuals on parental leave, fulltime family carers). Paid work represented a time constraint variable imposed by the person's involvement in an economic activity, which was also included in the selection models. The diary day was recoded into a binary variable: $1=$ weekday, $0=$ Saturday or Sunday. The models also controlled for the presence of children, the number of people in the household, education in years and age.

The substantive models additionally controlled for the province of residence because the province-level variation might not be accounted for by weighting procedures (Statistics Canada, 
2011). The models also included a few provincial-level variables in the analysis of the GSS data to account for structural-level differences. Thus, the provincial unemployment rate by year reported by the Economics and Statistics Branch (Statistics Canada, 2016), marriage rates per 1000 people by province and by year (Statistics Canada, 2015) and the percentage of women employed by province and by year (Ferrao, 2010) were added. Year variables were re-coded as dummy variables for each cycle of GSS.

\subsection{Analytical Approach}

The results were modelled at two stages. At the first stage, the selection bias was accounted for with respect to those who reported doing housework on the diary day compared to those who did not. Then, the association between economic resources and the time spent on housework among women and men was modelled on those who reported doing housework. The Heckman selection models included all independent variables in the substantive models (spline models) and variables that might have influenced the selection, especially other measures of economic resources omitted in the substantive models such as personal income, partners' income, time spent on paid work, whether the respondent is employed or not and homeownership. The substantive and selection models are available in the online supplement.

Based on the previous literature (Killewald and Gough, 2010; Hook, 2017), the association between resources and housework participation was analysed by using linear splines. In substantive models, the main independent variable (income transfer) was divided into three segments: lower, middle and upper terciles. Hook (2017) divided the splines into 0-50, 51-90 percentiles and the upper decile. The models in the present study did not follow Hook (2017) because terciles allowed to divide the sample into three main theoretical groups: economically 
dependent, equal earners and breadwinners. However, if the analysis is re-done using segment division as in Hook (2017), the main results of the present article remain the same.

A few robustness checks were conducted. The inclusion of the partner's income, household income, or both did not yield results significantly different from those presented in this work. All results were robust to the inclusion of the absolute income variable as a control not only in the selection models but also in the substantive models. However, the option for reporting models excluding the collinear controls measuring the same concept of economic resources was chosen in the present article.

\section{Results and Discussion}

Our findings provided support for the compensatory behaviour based on time availability and did not give enough evidence to support the gender deviance neutralisation hypothesis. Thus, compensatory behaviour happens among women and men due to the time constraint on weekdays. Overall, the results showed that there were considerable differences in the applicability of theoretical frameworks to the time spent by economically dependent (those who earned less than their spouses) and economically autonomous (those who earned more than their spouses) wives and husbands in housework types and by whether the diary day was on a weekday or weekend. Table 2 presents nine models predicting women's and men's hebdomadal housework participation in routine housework (cooking and cleaning), shopping and maintenance. Each block represents a separate model with tercile splines. Figures in this section plot the fitted values of housework participation by task and by weekday/weekend.

[Table 2 here] 


\subsection{Hypothesis 1. Hebdomadal Participation Differences}

Figure 1 (topmost panels) summarises the predicted housework participation for husbands and wives in routine housework based on the spline models. First, the results showed distinct patterns depending on whether routine housework tasks were performed on weekday or weekend. The present study reports, therefore, that the differences in weekday and weekend housework participation in the Canadian data were similar to those in the US, established in previous research (Hook, 2017).

Our study found that the resource-based framework applied to routine housework participation better on weekdays than on weekends. For example, the top left panel in Figure 1 shows that the participation in routine housework decreases depending on the level of resource contribution for women on weekdays (dashed line) but not on weekends (the dotted line in Figure 1 is flat and slightly increasing for breadwinner wives). Our results, therefore, confirmed Hook's (2017) findings that the resource-based frameworks could not account for the housework participation of women on weekends. However, the story is different for men. Their patterns of routine housework participation depended on resource contribution both on weekdays and on weekends (see the top right-side panel in Figure 1). Thus, our analysis confirmed Hypothesis 1.1 for women in routine housework but not for men.

The results, however, were more ambiguous for shopping and maintenance tasks but they gave us enough to aver that the gendered meanings around housework tasks were diverse and that routine housework was distinct from shopping and maintenance (Killewald and Gough, 2010). Both in shopping and maintenance, the participation of women and men did not depend on resource contribution (the patterns of participation were mostly flat regardless of income transfer). Moreover, there were no significant differences between weekday and weekend 
participation in these tasks (see Figure 1, where the confidence intervals for standard errors

overlap). Therefore, our results supported Hypothesis 1.2 and asserted that there were differences in the applicability of the resource-based and hebdomadal time constraint theses to different types of housework tasks. The implications of these findings are that the resource-based frameworks cannot account for the types of housework other than routine such as shopping and maintenance.

[Figure 1 here]

\subsection{Hypothesis 2. Hebdomadal Compensatory Behaviour with Gender Deviance Neutralisation}

Our results could not assert the presence of compensatory behaviour based on gender deviance neutralisation in routine housework among both gender groups. However, the compensatory behaviour was greater among breadwinner women in routine housework and among dependent men in shopping, but it was not on statistically significant level for the latter. Although the results may suggest that the compensatory behaviour was more gendered than not, it was not as clear in the Canadian data. The upper-right panel of Figure 1 shows that most breadwinner men compensated for their non-involvement on weekdays by involving more on weekends. Yet Table 2 shows that their participation in routine housework decreased with the level of their resource contribution (the regression coefficient is negative), whereas for breadwinner women, the association corresponded the expectations laid out by the gendercentred perspective: they increased their participation with the level of resource contribution. Thus, these findings could be viewed as a minor support for Hypothesis 2, although a more thorough investigation is due. Additionally, our results show that Hypothesis 2 could not be confirmed for shopping and maintenance housework tasks. 


\subsection{Hypothesis 3. Hebdomadal Compensatory Behaviour by Time Availability}

Figure 1 shows that among dependent and equal-earner men and women, the resourcebased framework could apply better on weekdays but not as readily among breadwinner wives and husbands. The findings summarised in the figure also confirmed that both among women and men, the performance of routine housework was higher on weekends. This trend was particularly clear among equal-earner women, breadwinner wives, and breadwinner husbands. Therefore, our results confirmed the compensatory behaviour based on time availability among wives and husbands, particularly among breadwinner wives and husbands (Hypothesis 3 ). The aggregate pattern (the darker line in Figure 1), which was analysed by Killewald and Gough (2010), conceals differences in weekday participation among women and men. Although Killewald and Gough (2010) report that compensatory housework participation does not take place, it is evident from the present results that the compensatory behaviour based on time constraint occurs on weekends in routine housework tasks.

Additionally, because our findings showed that the compensatory behaviour was present among men as well, the explanation of the hebdomadal compensatory behaviour based on time constraint could also account for the unusual pattern of American men's routine housework participation found by Kolpashnikova (2018), where breadwinner men increased their housework participation proportionally to the level of their resource contribution. It is likely to be the case that the compensatory behaviour on weekends among men tended to exceed the predicted time because weekend tasks required longer time commitments and men had the time to undertake such tasks on weekends. 
Furthermore, our findings varied by housework tasks. For instance, in shopping, women did not involve in compensatory behaviour but interestingly, there were unexpected differences between men's weekday and weekend participation in shopping activities (see Figure 1). Men spent more time on shopping tasks on weekdays than on weekends, although the coefficients did not differ significantly. Such pattern contradicts the hebdomadal time availability hypothesis for men in shopping tasks. Similarly, maintenance tasks appeared to be more of a weekday activity for both wives and husbands. The contradictory findings in maintenance can be explained by the character of some maintenance tasks. Many such tasks could be emergency tasks such as dealing with pipe bursts or leaking faucets.

Overall, our findings provided strong support for the compensatory behaviour proposition based on time availability tasks but not on gender deviance neutralisation in routine housework. The present study asserted that although there were discernible indicators of gender deviance neutralisation still evident in housework tasks, most hebdomadal compensatory behaviour was due to the time constraint faced by women and men on weekdays. The patterns established in the previous research for breadwinner women, whose participation in housework tasks did not depend on the level of resources (Killewald and Gough, 2010) or was reverse to the expectations of the resource-based framework (Brines, 1994; Greenstein, 2000), is due to the aggregation of weekday and weekend time commitments. Whereas the resource-based frameworks can account for the differences in routine housework participation on weekdays (when the time constraint is the highest), they cannot do so on weekends. The results also indicated that the cultural norms around who should do certain housework tasks also extended on when the said housework activity needed to be performed. These norms are indispensable to understanding and the analysis of housework participation. 


\section{Conclusion}

Our article explored the patterns of compensatory behaviour in housework tasks depending on whether the tasks were performed on a weekday or weekend. Our findings showed strong support for the hebdomadal character of compensatory behaviour among wives and husbands, especially in routine housework. For the most part, the time availability theoretical framework was apt to account for these patterns. The findings also showed that there were limitations to the conventional resource-based and gender-centred perspectives as they applied to weekend activities. The present study found that the resource-based explanations could apply mainly on weekdays but not on weekends. On the other hand, the gender-centred perspective offered a better explanation for breadwinner wives' housework time on weekends (the association between the level of resource contribution and housework participation was positive).

Our results, therefore, provide additional evidence for the hebdomadal character of housework participation among women and men. The compensatory behaviour reported in the previous literature and ascribed to gender deviance neutralisation concealed a substantial hebdomadal pattern. Moreover, because the compensatory behaviour was established both among women and men, the results indicated that compensatory behaviour might be more dependent on time availability rather than gender deviance neutralisation.

Some limited support was also found for compensatory behaviour based on gender deviance neutralisation. The amount of housework participation among breadwinner women was positively associated with the level of their resource contribution, especially on weekends, when they did more routine housework than on weekdays. The gender deviance neutralisation process for breadwinner wives, therefore, amplifies on weekends, implying that weekends transform the 
institution of marriage into a 'gender factory' (Berk, 1985). Further research using finer data could help with establishing whether the compensatory behaviour based on gender deviance neutralisation is actually present, specifically differentiating by welfare regimes. Most literature on the reported compensatory behaviour as discussed above confirmed the patterns of compensatory behaviour within the liberal welfare states (Lyonette and Crompton, 2015; Bittman et al., 2003; Evertsson and Nermo, 2004). Ours is no exception. The future research could focus on the development of a theory on whether or not similar results with regard to the hebdomadal compensatory behaviour based on the time constraint and gender deviance neutralisation should be expected in other regimes.

Two main extensions of the current theoretical stance can be proposed in the analysis of the gendered division of unpaid labour. First, the time availability and gender-centred perspectives should include the hebdomadal compensatory behaviour propositions, discussed in the theoretical part of our article. Second, our empirical findings also suggest that the current theoretical frameworks should account for the diversity in explanations for breadwinners, equalearners and dependents. Thus, the theoretical explanations that apply to principal breadwinners might not apply to dependent husbands and wives.

It must be taken into account that the empirical findings and theory regarding the hebdomadal compensatory behaviour apply more to the explanation of patterns in housework participation within gender groups. Thus, it has its limitations in application to the analysis of pattern differentials between gender groups. To compare the differences between gender groups, it might be more prudent to explore other methods such as the decomposition of the gender gap using couple-level data. 
Future research could also benefit from accounting for distinct factors driving the powerdynamics in equal-earner couples compared to breadwinner-dependent couples. Moreover, one of the limitations of the present study was that the current theory was not able to deal with the diversity of patterns in the association between resources and housework on weekends and in non-routine housework. Because other possibilities cannot be fully ruled out, the future studies should explore additional theoretical explanations to the patterns reported in the present study.

\section{Funding Information}

This project is funded by the European Research Council (ERC) under the European Union's Horizon 2020 research and innovation programme (awardee: Man Yee Kan; award 771736).

\section{References}

Adam B (1990) Time and Social Theory. Cambridge, UK: Polity Press.

Artis JE, Pavalko EK (2003) Explaining the decline in women's household labor: Individual change and cohort differences. Journal of Marriage and Family 65(3): 746-61.

Banister D (2011) The trilogy of distance, speed and time. Journal of Transport Geography 19(4): 950-959.

Baxter J, Hewitt B (2013) Negotiating domestic labor: Women's earnings and housework time in Australia. Feminist Economic 19(1): 29-53.

Berk SF (1985) The Gender Factory: The Apportionment of Work in American Households. New York, NY: Plenum.

Bianchi SM, Milkie MA, Sayer LC, and Robinson JP (2000) Is anyone doing the housework? Trends in the gender division of household. Social Forces 79(1): 191-228. 
Bittman M, England P, Sayer L, Folbre N, and Matheson G (2003) When does gender trump money? Bargaining and time in household work. American Journal of Sociology 109(1): $186-214$.

Blair SL, Lichter DT (1991) Measuring the division of household labor: Gender segregation of housework among American couples. Journal of Family Issues 12(1): 91-113.

Blood RO, Wolfe DM (1960) Husbands and Wives, the Dynamics of Married Living. New York, NY: The Free Press.

Brines J (1994) Economic dependency, gender, and the division of labor at home. American Journal of Sociology 100(3): 652.

Craig L (2007) How employed mothers in Australia find time for both market work and childcare. Journal of Family and Economic Issues 28(1): 69-87.

Deutsch FM (2007). Undoing gender. Gender and Society 21(1): 106-27.

Esping-Andersen G (1990). The Three Worlds of Welfare Capitalism. Cambridge, UK: Polity Press.

Evertsson M, Nermo M (2004) Dependence within families and the division of labor: Comparing Sweden and the United States. Journal of Marriage and the Family 66(5): 1272-86.

Ferrao V (2010) Paid Work. Ottawa, ON: Statistics Canada.

Fiorini M, Keane MP (2014) How the allocation of children's time affects cognitive and noncognitive development. Journal of Labor Economics 32(4): 787-836.

Glorieux I, Mestdag I, and Minnen J (2008) The coming of the 24-hour economy? Changing work schedules in Belgium between 1966 and 1999. Time and Society 17(1): 63-83.

Greenstein TN (2000) Economic dependence, gender, and the division of labor in the home: A replication and extension. Journal of Marriage and Family 62(2): 322-35. 
Gupta S (2007) Autonomy, dependence, or display? The relationship between married women's earnings and housework. Journal of Marriage and Family 69(2): 399-417.

Gupta S, Sayer LC (2014) Playing catch-up: Partnered women's housework on weekends versus weekdays. 2014 PAA Conference.

Heckman JJ (1979) Sample selection bias as a specification error. Econometrica 47(1): 153-61.

Hertog E, Iwasawa M (2011) Marriage, abortion, or unwed motherhood? How women evaluate alternative solutions to premarital pregnancies in Japan and the United States. Journal of Family Issues 32(12):1674-1699.

Higgins ET (1987) Self-discrepancy: A theory relating self and affect. Psychological Review 94(3): 319-340.

Hofferth SL, Casper LM (2007) Handbook of Measurement Issues in Family Research. Mahwah, NJ: Routledge.

Hook JL (2004) Reconsidering the division of household labor: Incorporating volunteer work and informal support. Journal of Marriage and Family 66(1): 101-17.

Hook JL (2017) Women's housework: New tests of time and money. Journal of Marriage and Family 79(1): 179-98.

Kan MY (2008a) Does gender trump money? Housework hours of husbands and wives in Britain. Work, Employment and Society 22(1): 45-66.

Kan MY (2008b) Measuring housework participation: the gap between 'stylised' questionnaire estimates and diary-based estimates. Social Indicators Research 86(3): 381-400.

Kan MY, He G (2018). Resource bargaining and gender display in housework and care work in modern china. Chinese Sociological Review 50(2): 188-230.

Kan MY, Pudney S (2008) Measurement error in stylized and diary data on time use. 
Sociological Methodology 38(1): 101-132.

Kan MY, Sullivan O, and Gershuny J (2011) Gender convergence in domestic work: Discerning the effects of interactional and institutional barriers from large-scale data. Sociology 45(2): $234-251$.

Killewald A, Gough M (2010) Money isn’t everything: Wives' earnings and housework time. Social Science Research 39(6): 987-1003.

Kitterød RH, Pettersen SV (2006) Making up for mothers' employed working hours? Housework and childcare among Norwegian fathers. Work, Employment and Society 20(3): 473-492.

Kolpashnikova K (2016) Housework in Canada: uneven convergence of the gender gap in domestic tasks, 1986-2010. PhD Thesis, University of British Columbia, Canada.

Kolpashnikova K (2018) American househusbands: new time use evidence of gender display, 2003-2016. Social Indicators Research 140(3): 1259-1277.

Kolpashnikova K, Kan MY, and Shirakawa K (2019a) Marriage and Housework: Analyzing the Effects of Education Using the 2011 and 2016 Japanese Survey on Time Use and Leisure Activities. IER Discussion Paper 696: 1-28.

Kolpashnikova K, Kan MY, and Shirakawa K (2019b) Marriage Penalty: Unconditional Quantile Regression of Housework Participation in Japan. IER Discussion Paper 695: 1-20.

Lyonette C, Crompton R (2015) Sharing the load? Partners' relative earnings and the division of domestic labour. Work, Employment and Society 29(1): 23-40.

McElroy MB, Horney MJ (1981) Nash-bargained household decisions: Toward a generalization of the theory of demand. International Economic Review 22(2): 333-49.

McLaughlin K, Muldoon O (2014) Father identity, involvement and work-family balance: An in-depth interview study. Journal of Community \& Applied Social Psychology 24(5): 439- 
452.

Mthombeni P, Casey ME (2019) The division of household labour by lesbian families residing in the northeast of England. Journal of GLBT Family Studies: 1-15.

Presser HB (1994) Employment schedules among dual-earner spouses and the division of household labor by gender. American Sociological Review 59(3): 348-64.

Ruppanner L, Treas J (2015) Working weekends: Changing European time regimes and gender inequality in household labor. Journal of Family Issues 36(13): 1782-1809.

Sorokin PA, Merton RK (1937) Social time: A methodological and functional analysis. American Journal of Sociology 42(5): 615-629.

Statistics Canada (2011) General Social Survey. Ottawa, ON: Author.

Statistics Canada (2015) Marriages and Crude Marriage Rates, Canada, Provinces and Territories, 1981 to 2008. Ottawa, ON: Author.

Statistics Canada (2016) Annual Average Unemployment Rate in Canada and Provinces, 19762015. Ottawa, ON: Author.

Sullivan O (2011) An end to gender display through the performance of housework? A review and reassessment of the quantitative literature using insights from the qualitative literature. Journal of Family Theory \& Review 3(1): 1-13.

Sykes GM, Matza D (1957) Techniques of neutralization: A theory of delinquency. American sociological review 22(6): 664-670.

West C, Zimmerman DH (1987) Doing gender. Gender and Society 1(2): 125-51.

Zhou M, Wu X, and He G (2017) Marriage in an immigrant society: Education and the transition to first marriage in Hong Kong. Demographic Research 37(18): 567-598. 
Kamila Kolpashnikova is a research fellow at the University of Oxford. She holds a PhD in sociology from the University of British Columbia. Her research interests include time use, gender and housework, North American and Japanese societies, Central Asian families, and national identity in Taiwan. She is a former recipient of the Japanese Government Monbukagakusho Scholarship at Tokyo University (2006-2011), the Rotary Foundation Ambassadorial Scholarship to Japan (2004-2005), Taiwan Fellowship (2018), and a visiting scholar at the Centre for Time Use Research and St Antony's College, Oxford University (2015)

Man-Yee Kan is an Associate Professor at the Department of Sociology, University of Oxford. Her research interests are gender inequalities in the family and the labour market, the gender division of labour, time use research, welfare and public policy regimes in Western and East Asian societies. She was awarded a British Academy Postdoctoral Fellowship (2008-2011) and a Research Councils UK Academic Fellowship (2008-2013). She has been awarded a European Research Council Consolidator Grant (2018-2023) for a project on the temporal structures of gender inequalities in East Asian and Western societies (GenTime; Grant Agreement Number 771736). 
Table 1. Descriptive Statistics of Main Variables

\begin{tabular}{lccc}
\hline Women & Weekdays & Weekends & Gap \\
\hline Domestic Tasks & 192.293 & 231.878 & $-39.585^{* * *}$ \\
& $(152.436)$ & $(162.851)$ & \\
Routine Tasks & 133.425 & 158.758 & $-25.333^{* * *}$ \\
& $(120.673)$ & $(132.945)$ & \\
Shopping Tasks & 53.371 & 64.964 & $-11.593^{* * *}$ \\
& $(86.423)$ & $(97.997)$ & \\
Maintenance Tasks & 5.496 & 8.155 & $-2.659^{* *}$ \\
& $(41.220)$ & $(50.646)$ & \\
\hline Men & Weekdays & Weekends & Gap \\
\hline Domestic Tasks & 86.207 & 154.563 & $-68.356^{* * *}$ \\
& $(117.694)$ & $(158.291)$ & \\
Routine Tasks & 37.978 & 64.915 & $-26.937^{* * *}$ \\
& $(62.870)$ & $(87.422)$ & \\
Shopping Tasks & 31.912 & 58.020 & $-26.108^{* * *}$ \\
& $(69.693)$ & $(101.209)$ & \\
Maintenance Tasks & 16.317 & 31.628 & $-15.311^{* * *}$ \\
& $(67.270)$ & $(99.509)$ & \\
\hline
\end{tabular}

${ }^{*} p<.05,{ }^{* *} p<.01,{ }^{* * *} p<.001$ All results are weighted. The descriptive statistics for other control variables are available upon request. 
Table 2. Heckman-adjusted Estimates for Married Women and Men in Housework

\begin{tabular}{|c|c|c|c|c|c|c|c|}
\hline & & $\begin{array}{l}\text { Model (1) Total } \\
\text { Women }\end{array}$ & $\begin{array}{c}\text { Model (2) } \\
\text { Weekdays Women }\end{array}$ & $\begin{array}{c}\text { Model (3) } \\
\text { Weekends Women }\end{array}$ & $\begin{array}{l}\text { Model (4) Total } \\
\text { Men }\end{array}$ & $\begin{array}{c}\text { Model (5) } \\
\text { Weekdays Men }\end{array}$ & $\begin{array}{c}\text { Model (6) } \\
\text { Weekends Men }\end{array}$ \\
\hline \multirow{4}{*}{ 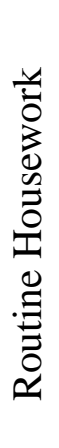 } & Share splines: & & & & & & \\
\hline & 0-32 percentile & $\begin{array}{c}-80.672^{* * *} \\
(7.644)\end{array}$ & $\begin{array}{c}-114.540^{* * *} \\
(8.737)\end{array}$ & $\begin{array}{c}1.314 \\
(14.603)\end{array}$ & $\begin{array}{c}-84.332^{* * *} \\
(19.758)\end{array}$ & $\begin{array}{l}-76.959^{* *} \\
(24.517)\end{array}$ & $\begin{array}{l}-95.786^{* *} \\
(32.110)\end{array}$ \\
\hline & $33-65$ percentile & $\begin{array}{l}-7.934 \\
(7.806)\end{array}$ & $\begin{array}{l}-15.591 \\
(8.439)\end{array}$ & $\begin{array}{c}11.316 \\
(17.138)\end{array}$ & $\begin{array}{l}-10.468 \\
(8.161)\end{array}$ & $\begin{array}{c}-25.719^{* *} \\
(8.657)\end{array}$ & $\begin{array}{c}20.709 \\
(17.610)\end{array}$ \\
\hline & $66-100$ percentile & $\begin{array}{c}8.676 \\
(9.870)\end{array}$ & $\begin{array}{c}3.429 \\
(10.921)\end{array}$ & $\begin{array}{c}23.970 \\
(20.433)\end{array}$ & $\begin{array}{l}-0.257 \\
(5.258)\end{array}$ & $\begin{array}{c}7.604 \\
(5.785)\end{array}$ & $\begin{array}{l}-16.391 \\
(10.616)\end{array}$ \\
\hline \multirow{3}{*}{$\begin{array}{l}\stackrel{00}{\mathscr{Z}} \\
\frac{\tilde{Z}}{2} \\
\frac{1}{n}\end{array}$} & 0-32 percentile & $\begin{array}{l}-21.262^{*} \\
(9.021)\end{array}$ & $\begin{array}{l}-21.614^{*} \\
(10.498)\end{array}$ & $\begin{array}{l}-18.691 \\
(16.706)\end{array}$ & $\begin{array}{c}17.163 \\
(24.941)\end{array}$ & $\begin{array}{l}-34.880 \\
(29.267)\end{array}$ & $\begin{array}{l}106.411^{* *} \\
(38.406)\end{array}$ \\
\hline & 33-65 percentile & $\begin{array}{l}-0.877 \\
(9.769)\end{array}$ & $\begin{array}{c}6.751 \\
(11.142)\end{array}$ & $\begin{array}{l}-15.099 \\
(18.859)\end{array}$ & $\begin{array}{l}-14.606 \\
(14.379)\end{array}$ & $\begin{array}{l}-16.845 \\
(16.746)\end{array}$ & $\begin{array}{l}-18.165 \\
(26.790)\end{array}$ \\
\hline & $66-100$ percentile & $\begin{array}{c}15.886 \\
(11.677)\end{array}$ & $\begin{array}{c}13.954 \\
(13.609)\end{array}$ & $\begin{array}{c}18.164 \\
(22.427)\end{array}$ & $\begin{array}{l}15.144 \\
(9.123)\end{array}$ & $\begin{array}{l}22.447^{*} \\
(10.629)\end{array}$ & $\begin{array}{c}2.648 \\
(16.157)\end{array}$ \\
\hline \multirow{3}{*}{ 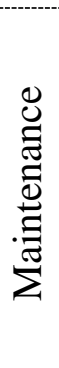 } & $0-32$ percentile & $\begin{array}{l}-37.895 \\
(38.380)\end{array}$ & $\begin{array}{l}-39.583 \\
(50.157)\end{array}$ & $\begin{array}{l}-66.866 \\
(69.713)\end{array}$ & $\begin{array}{l}-67.374 \\
(94.273)\end{array}$ & $\begin{array}{l}-12.534 \\
(96.301)\end{array}$ & $\begin{array}{l}-185.034 \\
(169.025)\end{array}$ \\
\hline & $33-65$ percentile & $\begin{array}{l}-23.564 \\
(48.383)\end{array}$ & $\begin{array}{l}-16.843 \\
(61.441)\end{array}$ & $\begin{array}{l}-21.583 \\
(85.273)\end{array}$ & $\begin{array}{c}-5.448 \\
(43.110)\end{array}$ & $\begin{array}{c}-5.481 \\
(44.406)\end{array}$ & $\begin{array}{c}-3.541 \\
(85.648)\end{array}$ \\
\hline & $66-100$ percentile & $\begin{array}{l}117.354 \\
(79.911)\end{array}$ & $\begin{array}{c}95.974 \\
(106.293)\end{array}$ & $\begin{array}{c}128.052 \\
(116.416)\end{array}$ & $\begin{array}{c}1.966 \\
(22.702)\end{array}$ & $\begin{array}{c}10.168 \\
(27.305)\end{array}$ & $\begin{array}{c}-5.753 \\
(38.382)\end{array}$ \\
\hline
\end{tabular}

Robust standard errors in parentheses ${ }^{*} p<0.05,{ }^{* *} p<0.01,{ }^{* * *} p<0.001$. Note: Models control for education, age, place of birth, children, children under 6 , household size, province-level unemployment rates, marriage rates, and female employment, year- and province-fixed effects. Selection models (Heckman) also include: time spent on paid work, employment status, homeownership, and personal income 
Routine Housework Tasks among Women (Splines), Canada

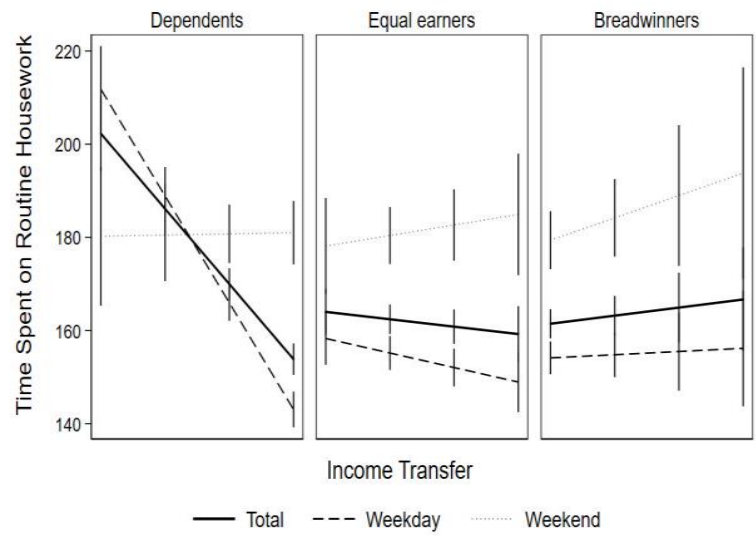

Shopping Tasks among Women (Splines), Canada

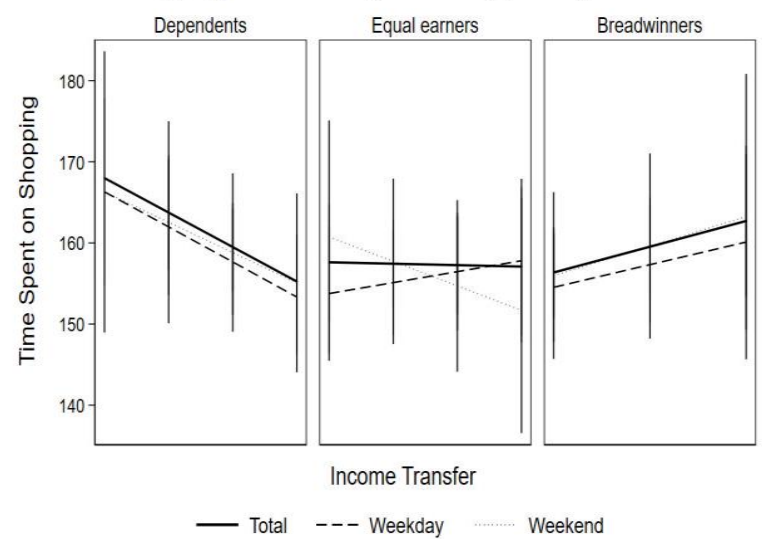

Maintenance Tasks among Women (Splines), Canada

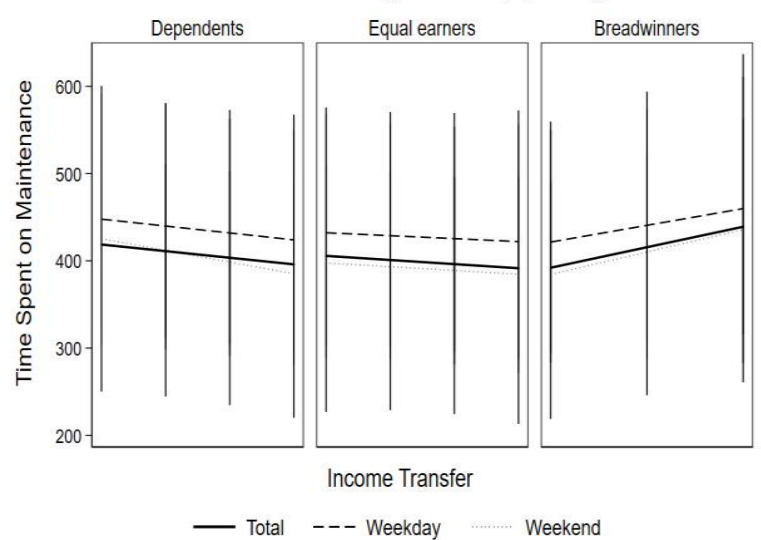

Routine Housework Tasks among Men (Splines), Canada

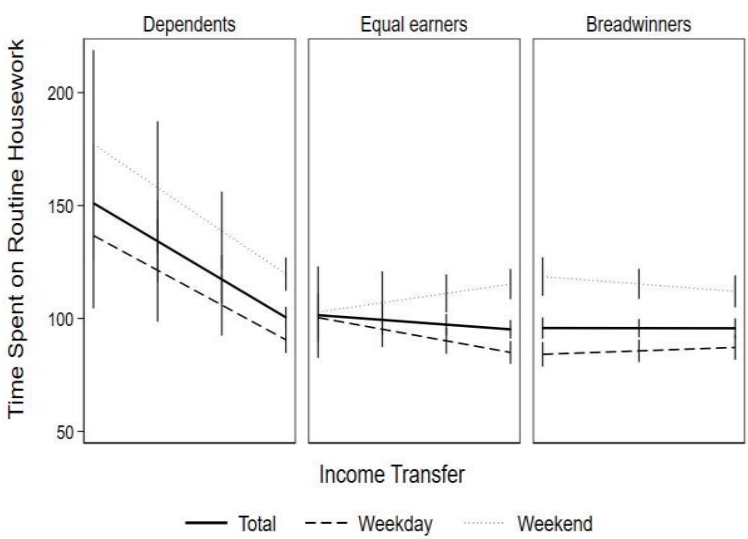

Shopping Tasks among Men (Splines), Canada

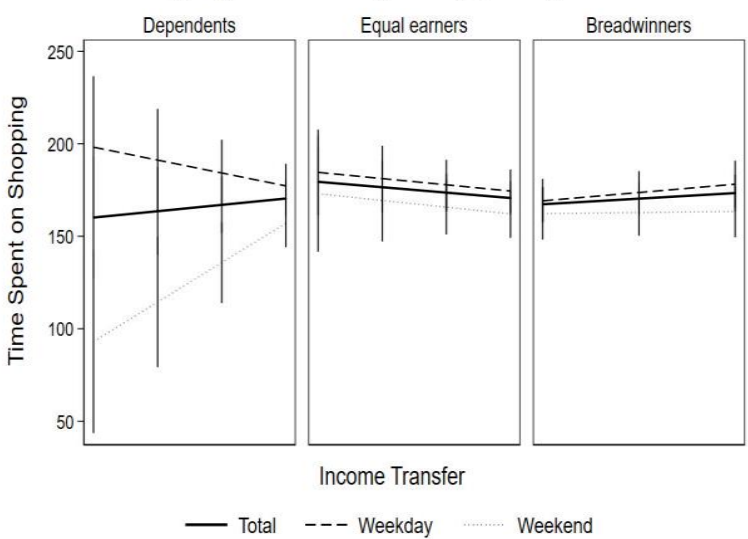

Maintenance Tasks among Men (Splines), Canada

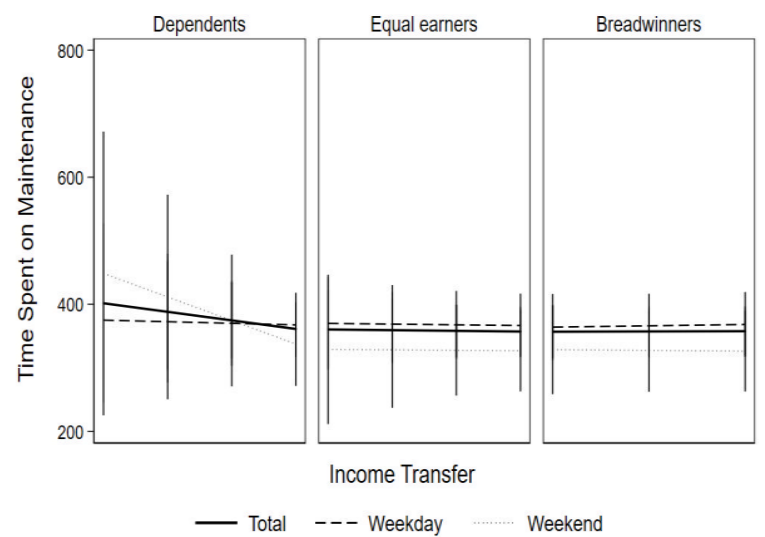

Figure 1. Predicted Values for Housework Participation by Income Transfer 